\title{
Örgütlerde Cinsel Yönelim Temeline Dayalı Kimlik: Farklılık Ikklimi Algısı, Bireysel Ve Örgütsel Çıktıların İncelenmesi*
}

\author{
Identity Based On Sexual Orientation In Organizations: Evolution Of Diversity \\ Climate Perception, Individual And Organizational Outcomes
}

\author{
Hazal Koray ALAY** \\ $\operatorname{Esin} C A N^{* * * *}$
}

\begin{abstract}
$\ddot{O} Z$
Bu araştırma da, çalışma yaşamında cinsel yönelim temeline dayalı kimliğin rolü incelenmektedir. Bu bağlamda, çalışanların farklılık iklimi algılarını ölçüp, cinsel yönelim farklılıklarının bireysel ve örgütsel çıtılır üzerindeki etkisinin geçerliliği ve geleceği tartışılmaktadır. Farklılıklar, farklılıkların yönetimi, farklılık iklimi literatüründen yararlanarak, sosyal kimlik teorisi ve cinsiyet rolleri teorisini temel alan bu makalenin araştırma yöntemi nicel desenlidir. Ortaya konan hipotezler, anket yönetimiyle temin edilen veriler aracıllğlyla test edilmiştir. Elde edilen verilere uygulanan analiz sonuçları modelin açıklayıcılık gücünün yüksek olduğunu göstermektedir. Cinsel yönelim farklılıkları algılanan farklılık iklimi, bireysel ve örgütsel çıktılar üzerinde farklılaştırıcı etkiye sahiptir. Daha önce sınırlı sayıda yapılan araştırmalarda da görülmektedir ki, çalışma yaşamındaki cinsel yönelim farklılıkların ne yönde değerlendirilmesi gerektiğine dair boşluk henüz doldurulamamıştır. Çalışma yaşamındaki farklılık iklimi algısını, bireysel çıktıları (iş tatmini, kariyer tatmini, örgütsel bă̆lılık) ve örgütsel çıktıları (iletişim ve işbirliği ortamı, davranışsal yenilikçilik, işten ayrılma niyeti) cinsel yönelime dayalı kimlik bağlamında inceleyen bu çalışmanın, ilgili yazına ve iş dünyasına katkı sağlaması amaçlanmaktadır.
\end{abstract}

\section{ANAHTAR KELIMELER}

Farklılıklar, Cinsel Yönelim Farklılıkları, Kimlik, Farklılık İklimi, Bireysel Ve Örgütsel Çıktılar

\begin{abstract}
In this study, while evaluating the role of identity based on sexual orientation in business life, measuring perception of diversity climate, also discussing the vality and future of the effect of sexual orientation differences on individual and organizational outcomes. In this context, this study based on the theory of social identiy and gender role theory also under cover of diversity, diversity management, diversity climate literature, tests the hypotheses revealed through the data provided by the survey. The results obtained from the analysis show that the model has a high explanatory power. Differences in sexual orientation have a differentiating effect on diversity climate perception, individual and organizational outcomes.. Despite the limited number of previous studies have shown that the gab of regarding diversity of sexual orientation should not filled yet. This study aims to contribute to the related literature and organizational life.
\end{abstract}

\section{KEYWORDS}

Diversities, Differences Of Sexual Orientation, Identity, Diversity Climate, Individual And Organizational Outcomes

\begin{tabular}{|c|c|c|}
\hline \multicolumn{2}{|r|}{$\begin{array}{c}\text { Makale Geliş Tarihi / Submission Date } \\
12.02 .2019\end{array}$} & $\begin{array}{c}\text { Makale Kabul Tarihi / Date of Acceptance } \\
12.04 .2019\end{array}$ \\
\hline Attf & $\begin{array}{l}\text { Alay, H.K. ve Can, E. (2019). Örgütle } \\
\text { ve Örgütsel Çıktıları İncelenmesi. Se }\end{array}$ & $\begin{array}{l}\text { neline Dayalı Kimlik: Farklılık İklimi Alg1s1, Bireysel } \\
\text { Bilimler Meslek Yüksekokulu Dergisi, } 22 \text { (1), 315-324. }\end{array}$ \\
\hline
\end{tabular}

\footnotetext{
* Bu çalışma birinci yazarın Yıldız Teknik Üniversitesi, Sosyal Bilimler Enstitüsü, Yönetim ve Örgütsel Davranış Anabilim Dalın da ikinci yazar danışmanlığında yürütmekte olduğu doktora tez çalışmasının bir bölümünü kapsamaktadır.

** Doktora Öğrencisi,Yılldız Teknik Üniversitesi, Sosyal Bilimler Enstitüsü, Yönetim ve Örgütsel Davranış Anabilim Dalı, hazalkoraygenc@gmail.com, ORCID: 0000-0002-6638-3089

**** Prof. Dr. Öğretim Üyesi, Yıldız Teknik Üniversitesi,İktisadi ve İdari Bilimler Fakültesi, İşletme Bölümü, esin.can@yildiz.edu.tr, ORCID: 0000-0002-5224-1987
} 


\section{GİRIŞ}

Farklılıklar neden örgütler için bu denli önemlidir sorusu, günümüz iş yaşamında cevaplanmayı bekleyen en önemli soruların başında gelmektedir. Farklılıklar örgütler için önemlidir ve bu önemliliği ortaya çıkaran birçok faktör vardır.Bu faktörlerin başında kadınların iş hayatındaki konumunun değişmesi ve sayılarının artması, köylerden kentlere hala yoğun bir iş göçünün yaşanması ile iş hayatındaki sosyo-kültürel yapının farklılaşması, farklı cinsel yönelime sahip çalışanların bunu ifade ediyor ve örgütleniyor olması, farklı politik, dinsel ve kültürel kimliğe sahip çalışanların varlığı gibi birçok faktör gelmektedir. Bu bağlamda örgütlerin farklılıkları görmezden gelmek yerine bu farklılıkları doğru şekilde yönetmesi ve destekleyici bir farklılık iklimi yaratması elzemdir.

Farklı1ıkları destekleyen bir örgüt ikliminin oluşturulması ve devamlılık kazanması, bireysel kariyer çıktılarını pozitif yönde etkilemekte ve örgütsel performansı arttırarak örgüt üyelerinin etkileşime girmelerini, birlikte uyum içinde çalışmalarını mümkün kılmaktadır. Ayrıca örgütlerin sürdürülebilir rekabetçi üstünlük kazanmalarının da önü açılmış olacaktır. Bu nedenle farklılıkların etkili bir şekilde yönetilmesi ihtiyacını gidermek gerekmektedir.

$\mathrm{Bu}$ çalışma, iş yaşamında cinsel yönelim temeline dayalı kimliğin rolüne dikkat çekerek, cinsel yönelim farklılıklarının bireysel ve örgütsel çıktılar üzerindeki etkisini incelenmektedir. Bu bağlamda farklılıklar, farklılıkların yönetimi, farklılık iklimi literatüründen yararlanarak; sosyal kimlik teorisi, eşitlik teorisi ve cinsiyet rolleri teorisini temel alan bu çalışma, ortaya konan hipotezleri, anket yönetimiyle temin edilen veriler aracılığılla test etmektedir. Bu kapsamda ilgili analizler yapılarak elde edilen sonuçlar ile araştırmacılara ve çalışma yaşamındaki tüm taraflara önerilerde bulunulmaktadır.

\section{TEORIKK ÖNGÖRÜ VE KAVRAMSAL ÇERÇEVE}

Cinsiyet stereotipleri, kadınların ve erkeklerin toplum içinde nasıl davranmaları gerektiğine ilişkin kuralları açıklamaları nedeniyle insanlar tarafından kullanılan yaygın bilişsel kısa yollardır (Eagly \& Karau, 2002). Cinsiyet doğal bir kategori olarak görülmekle birlikte cinsiyet rolleri bir kültürdeki normatif erkeklik ve kadınlık tarifiyle kaçınılmaz biçimde birbirine bağlıdır. Örneğin çocuk yetiştirmek için kadın gibi duygusal ve sabırlı olarak, asker olmak için de dayanıklı ve güçlü olmak gerekmektedir. Bu kalıp yargılar aslında biyolojik değil ideolojik ve toplumsaldır. Bu açıdan bakıldığında Pamuk'a (2017) göre, erkeklik ve kadınlık toplumun ürettiği toplumsal üretimler olarak değerlendirilmektedir. Bazı toplumsal yapısalcılar da benzer şekilde toplumsal cinsiyetin ne olduğumuzdan ziyade ne yaptığımız ve nasıl hissettiğimizle alakalı olduğunu savunmaktadırlar.

Toplumsal cinsiyetin bir yorumu olarak ortaya çıkan cinsellik ise dört temel kategoriye ayrılmaktadır. Bunlar biyolojik cinsiyet, toplumsal cinsiyet, toplumsal cinsiyet rolü ve cinsel yönelimdir (Weeks,2016). Biyolojik cinsiyet kadın ve erkeği tanımlayan biyolojik/bedensel ve fizyolojik özellikleri kapsamaktadır. Bir insanın dünyaya geldiği anda tanımlanan, üreme organlarına bakılarak genellikle penis, testisler, vajina, rahim, hormonlar, sperm ya da ovum (yumurta) üretebilme, doğurganllk yetisi ve benzeri biyolojik/anatomik özellikleri üzerinden tanımlanan cinsellik kategorisi biyolojik cinsiyettir. Toplumsal cinsiyet kültürden, coğrafyadan, tarihten etkilenen toplumsal olarak inşa edilmiş kadınlık ve erkeklik rollerinin, niteliklerinin ve sorumluluklarının tümünü kapsamaktadır. Toplumsal cinsiyet aile, iş ve arkadaş çevresi, gelenek ve görenekler, din, ordu, eğitim gibi birçok sosyal kurumdan etkilenmektedir. Toplumsal cinsiyet rolü bireyin kendini hangi cinsiyet üzerinden algıladığı, tanımladığı, hangi cinsiyete ait hissettiği ve hangi cinsiyetle özdeşleştirdiği ile ilgili bir kavramdır. Cinsel yönelim ise biyolojik cinsiyetten bağımsız olarak bireyin cinsel ve duygusal açıdan hangi cinsiyete ilgi duyduğu ile alakalıdır. Üzerinde durulması gereken bir diğer konu ise, cinsel yönelim tamlaması yerine günlük yaşamda sıklıkla kullanılan "cinsel tercih" tamlamasının kullanılmasıdır. Cinsel tercih tamlaması LGBTİ Hareketleri tarafından eleştirilmektedir. Onlara göre, cinsel yönelim bir tercih veya seçim değildir, insanların bilerek, isteyerek cinsel yönelimlerini seçmediklerini, arzu ettiklerinde eşcinselliği heteroseksüelliğe dönüştüremeyeceklerini belirtmektedirler (Altunpolat,2017). Bu bağlamda literatürde tanımlanmış olan ve LGBTİ Hareketlerinin kabul ettiği üç farklı cinsel yönelim türü bulunmaktadır. Bunlar;

-Heteroseksüel cinsel yönelim: Duygusal ve cinsel açıdan karşı cinsiyete ilgili duyan kadın veya erkeklerin sahip olduğu yönelimdir.

-Biseksüel cinsel yönelim: Duygusal ve cinsel açıdan hemcinsine ve karşı cinsiyete ilgi duyan kadın veya erkeklerin sahip olduğu yönelimdir.

-Eşcinsel cinsel yönelim: Duygusal ve cinsel yönelimin bireyin hemcinsine yönelik olmasıdır. Hemcinsine ilgi duyan kadın lezbiyen, hemcinsine ilgi duyan erkek gey olarak adlandırılmaktadır (KaosGL,2016). 
Toplumsal cinsiyet ve cinsel kimlik kategorilerinin sorgulanmasını sağlayan ve sosyoloji temelli seksoloji çalışmalarının sıklıkla referans aldığı Queer Teori alanda oldukça önemli yer tutmaktadır. Queer Teori, Postyapısalcı düşünürlerden olan Foucault'dan, Feminist teorilerden, Gey-Lezbiyen çalışmalarını temel almaktadır. Normalliği söküme uğratma gayesine odaklanan bu teori cinsiyet, cinsel yönelim, cinsellik temelli uygulamalarla ilgili tüm damgalamalara karşı durmaktadır. Kadınlık-erkeklik veya eşcinsellikheteroseksüellik gibi kimliklerin hiçbirinin tasnifinin doğal ve normal olmadığını, bu tasniflerin tarihsel, kültürel ve toplumsal olarak inşa edildiğini ve bu durumun baskın iktidar güç tarafından şekillendiğini savunmaktadır. Egemen olanın farklı olan üzerinde kurduğu tahakküm ve kısıtlamalara odaklanarak, hakim cinsiyet tarafından tanımlanmış normal ve sapkın kategorilerine karşı çıkmaktadır. Bunun yanında Queer teori yalnızca cinsel yönelim temelli kimliğe değil, sınıf, ırk, etnisite, engellilik gibi alanları incelemektedir (Özküralpli, 2016; Yardımcı ve Güçlü, 2013).

Cinsellik kategorilerinin yorumlanışı farklı cinsel yönelim kimliklerinin olumlanması anlamına gelmektedir. Fakat bu olumlamanın varlığını hissettiğimiz alanlar oldukça sınırlıdır. Bu bağlamda, cinsel yönelim farklılıklarının damgalanan bir kategoriye bürünmesi, eşcinsellerin yaşadıkları ayrımcılık ve toplumun zorunlu heteroseksüelliği benimsemesinden kaynaklanmaktadır. Akademik çevre tarafından da toplumsal bir konu olduğu gerçeği göz ardı edilmiş olan eşcinsellik, 1970'ler de Amerika ve Batı Avrupa da gey ve lezbiyen hareketlerinin başlamasıyla gündeme gelmiştir. Bu farkındalık eşcinsellere karşı güdülen düşmanlığı, dışlamayı, uygulanan ayrımcı politikaları çeşitli meslek alanlarının ve bilimsel çalışmaların inceleme konusu haline getirmektedir (Elçi,2018). Eşcinsellerin çalışma yaşamı içindeki varlıklarının incelediği yerli çalışmalar sınırlı olmakla birlikte, yabancı literatür de konuya dair farkındalık daha yüksektir. Hannekan ve Ladge (2017) tarafından ele alınan çalışmada, örgüt içindeki lezbiyenlerin farklılık iklimi algısının kurumsal bağlılık, iletişimde açıklık ve işten ayrılma niyetini etkilediği belirtilmektedir. Bell v.d. (2011) tarafından LGBT (lezbiyen, gey, biseksüel, transeksüel) çalışanların örgüt içindeki temsiliyetinin artırılmasına yönelik stratejiler geliştirdikleri çalışmalarında, bu çalışanların susturulmaların ortaya çıkardığı örgütsel sessizliğin sonuçları değerlendirmektedir. Day ve Schoenrade (2000) göre, cinsel yönelim farklılıkları ve iş tutumları arasındaki ilişki doğrulanmış, yönetimin desteği ve ayrımcı davranışların örgütsel bağlılık, iş tatmini ve çatışma davranışlarını etkilediği tespit edilmiştir. Ragins v.d. (2007) damgalama (stigma) teorisine dayandırdıkları çalışmada eşcinsel çalışanlarının korkularının iş tutumlarını, çalışma ortamını ve kariyer sonuçlarını etkilediği belirtilmektedir. Toplumsal kalıp yargılar, kadınlık ve erkeklik algısıyla şekillenen toplumsal cinsiyet rolleri kamusal alanda ve istihdam piyasasındaki cinsel yönelime dayalı ayrımcılıkla ilişkilendirilmektedir. Bu bağlamda cinsel yönelime dayalı ayrımcılık, bireysel bir sonuç olmanın ötesinde kurum/örgüt bazlı ve devlet yapısıyla bağlantılı derinlemesine incelenmesi gereken bir konudur (Öner, 2015).

Toplumların sahip oldukları hiyerarşik sistem biz ve ötekini tanımlarken keskin çizgilerle sınırlar koymaktadır. "Biz" kavramı ben, yerli olan, kural koyan, konuşan, yazan, akılcı olan, sınırları tanımlı ve kat1 olan; "öteki" kavramı ise onlar, yabanc1, kurallara tabi olan, dinleyen, okuyan, öznenin yaptığı planlamaya uyması beklenen, duygusal olan, sınırları değişebilir, muğlak olan ve özneye göre esnek olan" (Kundakçı, 2013: 69) şeklinde tanımlanmaktadır. Bu bağlamda, "ben/biz" kategorisi sakin, naif bir ev sahibi, "öteki/onlar" kategorisi ise düzen bozma eğilimli, saygısız ve tehlikeli misafirler olarak yorumlanabilmektedir. Bu tanımlamalar ile benzer olarak Bauman'ın (2003) "müphemlik" kavramını açıklarken LGBTİ bireyleri işaret eden, ötekinin muğlak, belirsiz, kategorilendirilemez, tanımlanamaz, sınıflanamaz niteliğine vurgu yapılmaktadır. Nitekim, bu algıya göre "ne olduğu belirsiz" olan öteki -LGBTİ birey- daima "düzen bozma potansiyeline" sahiptir.

Türkiye'de cinsel yönelim farklılıklarına yönelik çalışmaların sayısı oldukça azdır. Yapılan çalışmaların büyük çoğunluğu LGBT derneklerine üye eşcinsellerin toplum içerisinde yaşadıkları sorunları anlamaya yöneliktir. 2016 yılında Sivil Toplum Çalışmaları Merkezi (SYÇM), Sosyal Politikalar, Cinsiyet Kimliği ve Cinsel Yönelim Çalışmaları Derneği (SPoD) ve Sosyal Politika Forumunun (SPF) ortaklaşa yürüttüğü 2875 LBGT bireyle gerçekleştirilen çalışma da cinsel yönelim ve cinsiyet temeline dayalı kimlik ayrımcılığının yaratmış olduğu sosyal, psikolojik ve ekonomik sorunların sonuçları tartışılmıştır. Çalışma yaşamı içinde ayrımcıllığa maruz kalan LGBT bireylerin yasal yollara başvuramadıkları belirtilmiştir (Yılmaz ve Göçmen, 2015).

Türkiye anayasal düzen çerçevesinde eşcinselliği yasaklayan herhangi bir düzenleme olmamasına karşın, cinsel yönelim temeline dayalı kimliğe yönelik ayrımcı uygulamalar yaygındır. 1990'lardan beri her yıl yapılan Türkiye Değerler Araştırmasının kimlik kapsamında en istenmeyen grup eşcinseller olarak ortaya çıkmaktadır. Cinsel yönelimi farklı olan bireylerin maruz kaldığ 1 ayrımcı uygulamalar devlet, din, ordu ve hukuk gibi yapıların ürettiği söylemler sebebiyle çalışma hayatının tüm aşamalarında görülmektedir. Cinsel yönelim 
kimliği sebebiyle çalışanlar işlerinden çıkarılmakta, işten ayrılmaya zorlanmaktadırlar. Bu nedenlerle eşcinsel çalı̧̧anlar kimliklerini saklama, deşifre olmamak için başka bir kimliğe bürünmektedirler (Öner,2015). Kaos GL derneğinin 2018'de eşcinsel bireylerle yaptığı görüşmelerini içeren araştırmanın sonuçlarına göre, bireyler cinsel yönelimleri açıkladıklarında veya ifşa olduklarında ayrımcı uygulamalara maruz kaldıklarını belirtmişlerdir. Bu nedenle cinsel yönelimlerini gizli tutmayı tercih ettiklerini vurgulamışlardır. Heteroseksist ve homofobik toplumsal sterotiplere maruz kalan eşcinsel bireyler çoğunlukla heteroseksüel bir kimliğe sahipmiş gibi yaşamaktadırlar (Kabacağlu, 2015). Oysaki her bireyin kendini gerçekleştirmesinin temel bir insan hakkı olduğu bakış açısıyla hareket edilmesi, eşcinsel bireyleri de koruyucu hakların geliştirilmesi ve bu doğrultuda yasal uygulamaların ortaya konulması daha insani sonuçlar doğuracaktır.

$\mathrm{Bu}$ çerçevede cinsel yönelim temeline dayalı kimliğin, algılanan farklılık iklimini, bireysel çıktıları ve örgütsel çıktıları etkileyeceği söylenebilir. Bireysel çıktılar iş tatmini, kariyer tatmini ve örgütsel bağl1lık olarak, örgütsel çıktılar ise iletişim ve işbirliği ortamı, davranışsal yenilikçilik ve işten ayrılma niyeti olarak belirlenmiştir.

$H_{1}$ : Cinsel yönelim temeline dayalı kimliğin algılanan farklılık iklimi üzerinde farklılaştırıcı etkisi vardır.

$\mathrm{H}_{2:}$ Cinsel yönelim temeline dayalı kimliğin bireysel çıktılar (iş tatmini, kariyer tatmini, örgütsel bağlllı) üzerinde farklllaştırıcı etkisi vardır.

$H_{3:}$ Cinsel yönelim temeline dayalı kimliğin örgütsel çıktılar (iletişim ve işbirliği ortamı, davranışsal yenilikçilik ve işten ayrılma niyeti) üzerinde farklılaştırıcı etkisi vardır.

Çalışmamız kapsamında ilgili literatürden hareketle geliştirilen hipotezlerin sınanması amacıyla görgül bir araştırma yapılması planlanmış ve aşağıdaki araştırma modeli geliştirilmiştir.

\section{Şekil 1: Araştırma Modeli}

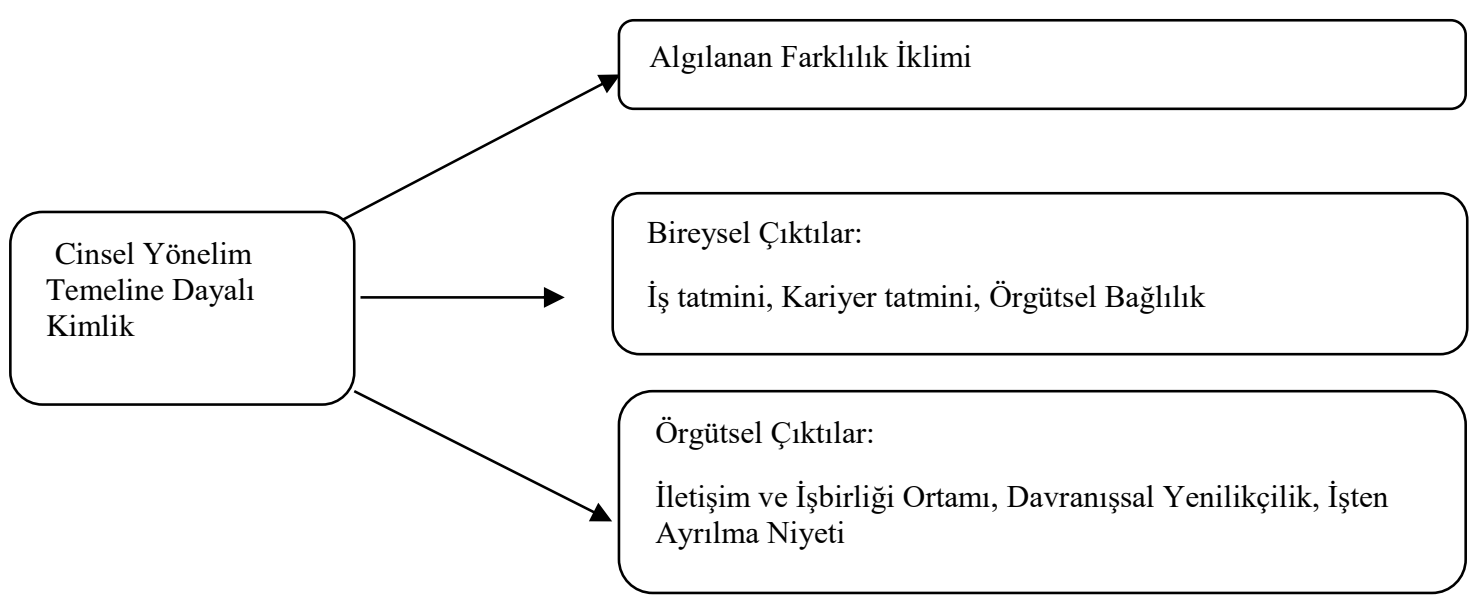

\section{YÖNTEM}

\subsection{Araştırmanın Yöntemi Kullanılan Ölçekler}

Araştırma amacı itibariyle açıklayıcı yaklaşıma sahiptir. Araştırma veri toplama ve analiz yöntemi açısından nicel bir çalışmadır. Analiz birimi açısından bireylerden veri alınarak, çalışılan örgütler bir bütün olarak değerlendirilmektedir. Araştırma kapsadığı süre bakımından kesitsel tarama yöntemine sahiptir. Araştırmanın örneklemini İstanbul ilinde istihdam ağı içinde yer alan farklı sektörlerin çalışanları oluşturmaktadır. Örneklem alanı olarak İstanbul'un seçilme nedenleri şu şekilde sıralanabilir:

- İstanbul'un toplam istihdam ağı içinde büyük bir orana sahip metropol olması

- İstanbul'un çok kültürlü bir yapıya sahip, farklı kimliklere sahip bireylerin bir arada yaşamasına imkan sunan bir şehir olması

- Cinsel yönelime dayalı farklılıklara farkındalığının yüksek olduğu bir şehir olması 


\subsection{Araştırmanın Örneklemi}

İstanbul'da istihdam ağı içinde yer alan aktif sigortalı çalışan sayısı (Sosyal Sigortalar Kurumu, Aralık,2018 verileri) 4 milyon 463 bindir. Yazıcıoğlu ve Erdoğan (2004: 50), $\alpha=0.05$ için +- 0.05 örnekleme hatası ile farklı evren büyüklüklerinden çekilmesi gereken örneklem büyüklükleri hesaplamasında 1 milyon ve üzeri evren büyüklüğü için 384 örneklem büyüklüğünün yeterli olduğu belirtmektedir. Bu araştırmada da bu hesaplama kullanılmıştır. Kartopu örnekleme türü ile ulaşılan çalışanlara mail yoluyla anket ulaştırılmış ve geri dönüş yapılan anket sayısı 534 olmuştur. Eksik ve hatalı kodlanan 2 anket tespit edildikten sonra araştırma kapsamına dahil edilen 532 çalışanın özellikleri şu şekildedir: Cinsel yönelime göre 451 heteroseksüel, 81 eşcinsel çalışan yer almaktadır.

\subsection{Kullanılan Ölçekler}

Araştırmada örgütlerde algılanan farklılık iklimini ölçmek için McKay, Avery ve Morris (2008) tarafindan geliştirilen 4 ifadeden oluşan ölçek; işten ayrılma niyetini ölçmek için McKay, Avery, Tonidandel, Morris, Hernandez ve Hebl (2007) tarafindan geliştirilen 2 ifadeden oluşan ölçek, örgütsel bağlılığı ölçmek için McKay v.d.'nin (2007) geliştirdikleri 4 sorudan ölçek, iş tatminini ölçmek için Brimhall, Lizano ve Mor Barak (2014) tarafindan geliştirilen 4 ifadeden oluşan ölçek; kariyer tatminini ölçmek için Greenhaus, Parasuraman, Wormley (1990) taraflarından geliştirilen 5 ifadeden oluşan ölçek; iletişim ve işbirliği ortamı algısını ölçmek için Avcı (2005) tarafından geliştirilen 7 ifadeden oluşan ölçek; davranışsal yenilikçiliği ölçmek için Wang ve Ahmed (2012) tarafından geliştirilen 4 ifadeden oluşan ölçek kullanılmıştır. Araştırmada kullanılan ölçeklerin güvenilirlik katsayıları 0,80'nin üzerindedir.

\subsection{Araştırmanın Sınırlılıkları}

Araştırmanın gerçekleştirildiği tarihlerde meydana gelen siyasal ve ekonomik gelişmeler sebebiyle, çalışanların işlerini kaybetme korkusuyla ve endişesiyle cevapları yanlı vermeleri veya araştırmaya katılmayı reddetmeleri bu çalışmada önemli bir kısıttır. Ayrıca çalışanların cinsel yönelimlerini açılamaktan çekinmelerine neden olan ülkedeki toplumsal normlarında veri toplama sürecinde oldukça olumsuz etkisi olduğu bilinmelidir.

\section{BULGULAR}

Araştırma veri toplama ve analiz yöntemine göre nicel bir araştırmadır. Bu doğrultuda araştırmaya konu olan modeli test etmek için, SPSS 20 paket programı ile öncelikle normal dağılım testi yapıldıktan sonra, değişkenlerin geçerlilik ve güvenilirliği, açıklayıcı faktör analizi ve güvenilirlik analizi yöntemleri kullanılarak değerlendirilmiştir. Daha sonra hipotezleri test etmek için bağımsız örneklem $t$ testi yöntemi uygulanmıştır.

\subsection{Değişkenlere Ait Faktör Ve Güvenilirlik Analizleri}

Çalışmada değişkenlere öncelikle açıklayıcı faktör analizi uygulanmıştır. Faktör analizinde, örneklem yeterliliğini ölçmek içi Kaiser-Meyer- Olkin (KMO) testi yapılmıştır. KMO değerinin 0,5 in üzerinde olması veri setinin faktör analizi yapmak için uygunluk seviyesinin yüksek olduğunu göstermektedir (Durmuş vd.,2012:54). Güvenilirlik analizi yapılırken alpha modeli kullanılmıştır. Cronbach's alpha sorular arası korelasyona bağlı uyum değeridir. Bu değerin 0,70 ve üstü olması ölçeğin güvenilir olduğunu göstermektedir. Bu bağlamda değişkenlere uygulanan analiz sonuçları sırasıyla Tablo 1, Tablo 2 ve Tablo 3 'te yer almaktadır. Tablolar da görüldüğü üzere güvenilirlik katsayıları farklılık iklimi değişkeninin 0,872; bireysel kariyer çıktıları değişkenlerinden iş tatmininin 0,918 kariyer tatmininin 0,921 örgütsel bağgl1lığın 0,941; örgütsel çıktılar değişkenlerinden davranışsal yenilikçiliğin 0,906 iletişim ve işbirliği ortamının 0,904 işten ayrılma niyetinin 0,768 olarak tespit edilmiştir. İşten ayrılma niyetinin diğerlerine göre nispeten düşük olmasının nedeninin soru sayısı ile alakalı olduğu düşünülmektedir. 
Tablo 1: Algılanan farklıık iklimi değişkenine yönelik faktör ve güvenilirlik analizi sonuçları

\begin{tabular}{|lcc|}
\hline FARKLILIK İKLIMİ & $\begin{array}{c}\text { Faktör } \\
\text { Yükü }\end{array}$ & $\begin{array}{c}\text { Cronbach } \\
\text { Alpha }\end{array}$ \\
\hline Çalıştığım iş yerinin bana adil davranacağına inanırım. &, 896 &, 870 \\
$\begin{array}{l}\text { Çalıştığım iş yeri farklılık dostu, çeşitliliği teşvik eden bir çalışma } \\
\text { ortamı sunar. }\end{array}$ &, 872 &, 853 \\
$\begin{array}{l}\text { Çalıştığım iş yeri benim gibi insanların görüşlerine) saygı duyar. } \\
\begin{array}{l}\text { Üst/tepe yönetim çeşitliliği /farklılıkları görünür/açık şekilde teşvik } \\
\text { eder/destekler. }\end{array}\end{array}$ &, 845 &, 839 \\
\hline $\begin{array}{l}\text { \%Açklanan Varyans:80,637 } \\
\text { Kaiser-Meyer-Olkin Measure of Sampling Adequacy=0.835 } \\
\text { Chi-Square Bartlett's Test=1071,433 }\end{array}$ & & \\
\hline
\end{tabular}

Tablo 2: Bireysel kariyer çıktıları değişkenlerine yönelik faktör ve güvenilirlik analizi sonuçları

\begin{tabular}{|c|c|c|}
\hline BİREYSEL KARIYYER ÇIKTILARI & $\begin{array}{r}\text { Faktör } \\
\text { Yükü }\end{array}$ & $\begin{array}{l}\text { Cronbach } \\
\text { Alpha }\end{array}$ \\
\hline İş Tatmini & & 0,918 \\
\hline Bütün olarak değerlendirildiğinde işimden memnunum. & ,807 & ,882 \\
\hline İşim ive işyerimi yakın bir arkadaşıma tavsiye ederim &, 817 &, 884 \\
\hline $\begin{array}{l}\text { İşimle ilgili şuan bildiklerimi göz önünde bulundurduğumda, bugün başa } \\
\text { dönsem yine bu işi isterim. }\end{array}$ & 885 & ,903 \\
\hline $\begin{array}{l}\text { Genel olarak işimin, bu işe girdiğim zamanki beklentilerimi karşıladığını } \\
\text { söyleyebilirim. }\end{array}$ & ,897 & ,904 \\
\hline Kariyer Tatmini & & 0,921 \\
\hline Kariyerimde ulaştığım başarıdan tatminim. & ,858 & ,903 \\
\hline Genel kariyer hedeflerime ulaşma yolunda yaptığım ilerlemeden tatminim. & 836 & ,923 \\
\hline Hedeflediğim gelire ulaşma yolunda yaptığım ilerlemeden tatminim. &, 875 & ,898 \\
\hline Terfi hedeflerime ulaşma yolunda yaptığım ilerlemeden tatminim. & ,877 & ,901 \\
\hline $\begin{array}{l}\text { Yeni beceriler geliştirme hedeflerime ulaşma yolunda yaptığım ilerlemeden } \\
\text { tatminim. }\end{array}$ & ,910 & ,919 \\
\hline Örgütsel Bağlılık & & 0,941 \\
\hline Çalıştığım iş yeri her gün işimi en iyi şekilde yapmam için bana ilham verir. & ,786 & ,928 \\
\hline $\begin{array}{l}\text { İş yerim, işimi yaparken gerekenden daha fazla katkı sağlamam için beni } \\
\text { motive eder. }\end{array}$ & ,780 & ,917 \\
\hline $\mathrm{Bu}$ iş yerinde çalışmayı başkalarına öneririm. & ,791 & ,927 \\
\hline Bu iş yerini çalışllacak bir yer olarak notlandırırken yüksek puan veririm. & ,786 & ,918 \\
\hline $\begin{array}{l}\text { \%Açılkanan Varyans:84,040 } \\
\text { Kaiser-Meyer-Olkin Measure of Sampling Adequacy=0.889 } \\
\text { Chi-Square Bartlett's Test=6130,649 }\end{array}$ & & \\
\hline
\end{tabular}


Tablo 3:Örgütsel çıktılar değişkenlerine yönelik faktör ve güvenilirlik analizi sonuçları

\begin{tabular}{|c|c|c|}
\hline ÖRGÜTSEL ETKİLİLIKK ÇIKTILARI & $\begin{array}{l}\text { Faktör } \\
\text { Yükü }\end{array}$ & $\begin{array}{l}\text { Cronbach } \\
\text { Alpha }\end{array}$ \\
\hline Davranışsal Yenilikçilik & & 0,906 \\
\hline $\begin{array}{l}\text { İşyerimizde, işini farklı yollar/yöntemler kullanarak yapanlara hoşgörü } \\
\text { gösterilir. }\end{array}$ & 828 & 890 \\
\hline $\begin{array}{l}\text { Kurumumuzdaki çalş̧anlar, orijinal ve özgün düşünme/davranma } \\
\text { konusunda cesaretlendirilir. }\end{array}$ & ,773 & 853 \\
\hline $\begin{array}{l}\text { İşimizle ilgili farkl1/özgün çözümler arama ve yeni yollarla/yöntemlerle } \\
\text { yapmayı deneme konusunda arzuluyuz }\end{array}$ & 872 & ,902 \\
\hline $\begin{array}{l}\text { İşimizle ilgili yeni yollar/yöntemler denemek istediğimizde } \\
\text { yöneticilerimizden yoğun destek görürüz. }\end{array}$ & 819 & 864 \\
\hline İletişim ve İşbirliği Ortamı & & 0,904 \\
\hline İşyerimizde kişiler arası diyaloglar etkili ve olumludur. & ,867 & ,885 \\
\hline $\begin{array}{l}\text { İşyerimizde, çalışanlar arasında yüksek düzeyde güven duygusu } \\
\text { oluşmuştur. }\end{array}$ & ,884 & 880 \\
\hline $\begin{array}{l}\text { İşyerimizde, kişiler ve departmanlar arasında fazla çatışma } \\
\text { yaşanmamaktadır. }\end{array}$ & 833 & 892 \\
\hline İşyerimizde yaşanan çatışmalar yıkıcı değildir & ,900 & ,886 \\
\hline İşyerimizde, kişiler arası uyuşmazlıklarla sık karşılaşılmamaktadır & ,932 & ,884 \\
\hline $\begin{array}{l}\text { İşyerimizde ekip çalışmasının geliştirilmesi ve takım ruhunun oluşturulması } \\
\text { için çaba sarf edilmektedir. }\end{array}$ & ,868 & 886 \\
\hline İşyerimizde değişime karşı direnç yüksek değildir & ,967 & ,911 \\
\hline İşten Ayrılma Niyeti & & 0,868 \\
\hline İşimden ayrılmayı neredeyse hiç düşünmüyorum & ,901 & 865 \\
\hline $\mathrm{Bu}$ iş yerinden ayrılmam çok zor & ,913 & 867 \\
\hline $\begin{array}{l}\text { \%Aç1klanan Varyans:84,985 } \\
\text { Kaiser-Meyer-Olkin Measure of Sampling Adequacy=0.934 } \\
\text { Chi-Square Bartlett's Test=6130,649 }\end{array}$ & & \\
\hline
\end{tabular}

\subsection{Hipotezlerin Test Edilmesi ve Yorumlanması}

Araştırma modelindeki hipotezleri test etmek için bağımsız gruplar t-testi yöntemi kullanılmıştır. Bağımsız gruplar t-testi iki bağımsız grubun ortalamalarının birbirinden farklı olup olmadığını test etmek amacıyla kullanılan istatistiksel analiz yöntemidir. Bağımsız gruplar t-testinde karşılaştırılan birbirinden bağımsız heteroseksüel ve eşcinsel grupların varyanslarının eşitliği Levene testi ile yapılmaktadır. Bu bağlamda, cinsel yönelim temeline dayalı kimliğin farklılık iklimi algısı, iş tatmini, kariyer tatmini, örgütsel bağlılık, iletişim ve işbirliği ortamı, davranışsal yenilikçilik, işten ayrılma niyeti üzerinde herhangi bir farklılaştırıcı etkisi olup olmadığı incelenmiştir. Elde edilen sonuçlar Tablo 4’te özetlenmiştir. 
Tablo 4:Bağımsız gruplar t-testi analizi sonuçları

\begin{tabular}{|c|c|c|c|c|c|c|c|}
\hline \multicolumn{2}{|c|}{ Cinsel Yönelim } & $\mathbf{N}$ & Ort. & S.D. & Varyans & $\mathbf{t}$ & $\mathbf{p}$ \\
\hline $\begin{array}{c}\text { Algılanan } \\
\text { Farklılık } \\
\text { İklimi }\end{array}$ & $\begin{array}{c}\text { Heteroseksüel } \\
\text { Eşcinsel }\end{array}$ & $\begin{array}{c}451 \\
81\end{array}$ & $\begin{array}{l}3,4063 \\
2,1282 \\
\end{array}$ & $\begin{array}{l}1,09664 \\
1,35523\end{array}$ & eşit & 9,507 & 0.00 \\
\hline İş tatmini & $\begin{array}{c}\text { Heteroseksüel } \\
\text { Eşcinsel }\end{array}$ & $\begin{array}{c}451 \\
81\end{array}$ & $\begin{array}{l}3,3484 \\
2,0615\end{array}$ & $\begin{array}{l}1,19727 \\
1,28060\end{array}$ & eşit & 8,921 & 0.00 \\
\hline $\begin{array}{l}\text { Kariyer } \\
\text { tatmini }\end{array}$ & $\begin{array}{c}\text { Heteroseksüiel } \\
\text { Eşcinsel }\end{array}$ & $\begin{array}{c}451 \\
81\end{array}$ & $\begin{array}{l}3,4583 \\
3,1074\end{array}$ & $\begin{array}{l}1,08186 \\
1,11532\end{array}$ & eşit & 2,887 & 0.00 \\
\hline $\begin{array}{l}\text { Örgütsel } \\
\text { Bağlılık }\end{array}$ & $\begin{array}{c}\text { Heteroseksüiel } \\
\text { Eşcinsel }\end{array}$ & $\begin{array}{c}451 \\
81\end{array}$ & $\begin{array}{l}3,1325 \\
1,8795\end{array}$ & $\begin{array}{l}1,23275 \\
1,24334\end{array}$ & eşit & 2,196 & 0.00 \\
\hline $\begin{array}{c}\text { İşten ayrılma } \\
\text { niyeti }\end{array}$ & $\begin{array}{c}\text { Heteroseksüiel } \\
\text { Eşcinsel }\end{array}$ & $\begin{array}{c}451 \\
81\end{array}$ & $\begin{array}{l}3,1424 \\
1,9123\end{array}$ & $\begin{array}{l}1,26068 \\
1,25978\end{array}$ & eşit & 8,135 & 0.00 \\
\hline $\begin{array}{c}\text { İletişim ve } \\
\text { İşbirliği } \\
\text { Ortamı } \\
\end{array}$ & $\begin{array}{c}\text { Heteroseksüel } \\
\text { Eşcinsel } \\
\end{array}$ & $\begin{array}{c}451 \\
81\end{array}$ & $\begin{array}{l}3,3231 \\
2,9424\end{array}$ & $\begin{array}{l}\text {,98219 } \\
, 96890\end{array}$ & eşit & 3,969 & 0.00 \\
\hline $\begin{array}{l}\text { Davranışsal } \\
\text { Yenilikçilik }\end{array}$ & $\begin{array}{c}\text { Heteroseksüel } \\
\text { Eşcinsel }\end{array}$ & $\begin{array}{c}451 \\
81\end{array}$ & $\begin{array}{l}3,2980 \\
2,1282\end{array}$ & $\begin{array}{l}1,10019 \\
1,18081\end{array}$ & eşit & 7,918 & 0.00 \\
\hline
\end{tabular}

Tablo 4'te görüldüğü üzere, $\mathrm{p}$ değerlerinin anlamlılığının tespit edilmesi, karşılaştırılan grupların algılarının farklılık gösterdiği anlaşılmaktadır. Hangi grup lehine bir farklılık olduğunu anlamak için grup ortalamalarına bakılmaktadır. Algılanan farklılık iklimi için eşcinsellerin heteroseksüellere göre anlamlı derecede olumsuz olduğu görülmektedir. Algılanan farklılık iklimini ölçen sorular göz önüne alındığında, eşcinsellerin çalışma ortamlarının farklılıkları desteklemeyen, farklılıklara saygı duymayan, adil olmayan bir atmosfere sahip olduğu çıkarımında bulunulabilir. Benzer şekilde eşcinsellerin iş tatmini, kariyer tatmini ve örgütsel bağlılığı heteroseksüellere göre anlamlı derecede azdır. Eşcinsellerin yaptıkları işten ve iş yerlerinden tatmin duymadıklarını, bu durumun örgütsel bağlılık düzeyinde de kendini benzer olumsuz algı ile gösterdiği söylenebilir. Eşcinsellerin heteroseksüellere göre, örgütsel bir çıktı olan işten ayrılma niyetinin de olumsuz olan bu algılarla şekillenip anlamlı derecede farklılaştığı görülmektedir. İş yerinde tatmin duymayan, bağlılık hissetmeyen eşcinsellerin iletişim ve işbirliği ortamı algısı da heteroseksüellere göre anlamlı derecede olumsuzdur. Davranışsal yenilikçiliğin örgütün kültürü ve iklimi ile şekillendiği göz önüne alındığında, eşcinsellerin çalışma ortamlarını farklı düşüncelerin bastırıldığı veya desteklenmediği, yenilikçiliğe kapalı olarak değerlendirdikleri tespit edilmiştir.

Analiz sonuçları modelin açıklayıcılık gücünün yüksek olduğunu göstermektedir. Cinsel yönelim farklılıkları algılanan farklılık iklimi, bireysel ve örgütsel çıktılar üzerinde farklılaştırıcı etkiye sahiptir. Bu bulgular ilgili alan yazında daha önce yapılmış çalışmalarla uyuşmaktadır (Hannekan ve Ladge,2017; Bell v.d.,2011; Day ve Schoenrade, 2000,2006; Ragins v.d.,2007; Colgan ve Rumens,2015; Syed ve Özbilgin,2015; Öztürk,2011). Eşcinsellerin çalışma ortamında algıladıkları farklılık iklimi heteroseksüellere göre daha olumsuzdur. Ayrıca eşcinsellerin iş ve kariyer tatmini, örgütsel bağl1lı̆̆ heteroseksüellere göre oldukça düşüktür. Bu durum çalışanların maruz kaldığı damgalanma, dışlanma, ötekileştirilme gibi davranışlarla ilişkilendirilebilir. Diğer taraftan eşcinsellerin örgütsel çıktılar değişkenlerinden iletişim ve işbirliği ortamı heteroseksüellere oranla daha güvensiz ve yıkıcı olarak değerlendirilmiştir. Benzer şekilde eşcinsellerin davranışsal yenilikçilik değişkenine yönelik algıları heteroseksüellere göre oldukça olumsuzdur.

Amerika Birleşik Devletleri'nde tahmini 8,8 milyon ve Birleşik Krallık'ta yaklaşık 4 milyon LGBT birey potansiyel çalışan, önemli satın alma gücüne sahip müşteri, ilgi ve etkiye sahip paydaş konumundadır. Bu bağlamda ilgili ülkelerde yapılan çalışmaların odak noktası farklılıklara değer veren işverenlerin, çalışanları işe çekme ve işte tutma konusunda avantajlara sahip olacağını ve bu tutumun müşteri kazanımını da etkileyeceğini göstermektedir (Cox ve Blake,2018). 


\section{SONUÇ VE ÖNERILER}

Ayrımcılık, sosyolojik, psikolojik ve ekonomik sonuçları olan bir kavramdır. Ayrıca, ayrımcılık devletlerin gerekli yasal düzenlemeler ile ortadan kaldırmaya yönelik çalışmalar yürüttüŭg̈ bir sorundur. Türkiye'nin uyum sağladığı uluslararası mevzuatlardan olan İnsan Hakları Evrensel Beyannamesi, "Ekonomik, Kültürel, Sosyal Haklar Sözleşmesi”, Uluslararası Çalışma Örgütü’nün (ILO) 111 Sayılı "İs ve Meslekte Ayrımcılığın Önlenmesi Sözleşmesi”, AB 2000/78 Sayılı Çerçeve Yönergesi ayrımcılığı önleme ve yasaklamaya yöneliktir. Türkiye Cumhuriyeti Anayasasının 10. maddesine göre de "herkes, dil, 1rk, renk, cinsiyet, siyasi düşünce, felsefi inanç, din, mezhep ve benzeri sebeplerle ayırım gözetilmeksizin kanun önünde eşittir.” kanun önünde kimse sahip olduğu kimlik yapıları sebebiyle ayrımcıllğa maruz kalamaz. Benzeri hüküm İş Kanunun 5. maddesinde de geçerlidir. Ancak yasal düzenlemelerin varlığı ayrımcılığı tümüyle ortadan kaldırmamaktadır. Toplum yaşam içinde birçok birey ayrımcılığa maruz kalmaktadır. Bu durum en yaygın şekilde çalışma yaşamı içinde görülmektedir. Çalışma yaşamı içinde engellilik, cinsiyet, yaş temelli kimlik yapılarının maruz kaldığ 1 ayrımcılık farklı platformda sesini duyurabiliyorken, cinsel yönelim temeline dayalı kimliğe yönelik ayrımcılık çok kısıtlı ve sınırlı bir alanda kendine yer bulmaktadır. Bu durumda cinsel yönelim temeline dayalı kimliğe farkındalığı azaltmaktadır.

Daha önce yapılan çalışmalara rağmen cinsel yönelim farklı1ıkların ne yönde değerlendirilmesi gerektiğine dair boşluk henüz doldurulamamıştır. Bu çalışmanın cinsel yönelim temeline dayalı kimliğe yönelik farkındalığı ve görünürlüğü artırması umut edilemektedir. Çalışma yaşamındaki farklılık iklimi algısını, bireysel ve örgütsel çıktıları, cinsel yönelime dayalı kimlik bağlamında inceleyen bu çalışmanın, ilgili yazına ve iş dünyasına katkı sağlaması amaçlanmaktadır. Bu bağlamda yapılacak öneriler şu şekilde sıralanabilir:

- Çalışma yaşamı içindeki tüm taraflar toplumsal kalıp yargılarla hareket etmekten vazgeçmelidir.

- Örgütlerin eşcinsel çalışanlarından daha yüksek düzeyde memnuniyet, kurumsal bağl1lık ve olumlu çalışma tutumları bekleyebilmeleri için, farklılıkları doğru yönetmeleri gerekmektedir.

- Örgütler farkl11ıklara değer vermelidirler.

- Örgütler eşit firsat dağılımı ilkeleri benimsenmelidir.

- Örgütlerin insan kaynakları yöneticileri eşcinsel çalışanları diğer çalışanlardan ayırmayan eşitlikçi politikalar ve uygulamalar geliştirmelidirler.

- LGBT çalışanlar heteroseksizme karşı toleranslı kuruluşlar aramak için daha bilinçli çaba göstermelidirler.

- Örgütsel sessizliği önlemek için demokratik ve adil ses mekanizmaları geliştirilerek örgüt içinde azınlık grupların sesi teşvil edilmelidir.

- Yöneticiler ve insan kaynakları uzmanları farkl11ıkların avantaja dönüştürülebileceği bilincinde olmalı ve örgüt politikalarına ayrımcılık karşıtı ve ayrımcılığı önleyici uygulamalar eklemeli, uygulamalidırlar. 


\section{KAYNAKÇA}

Altunpolat, R. (2017) “LGBTI'LERE YÖNELIK AYRIMCILIĞI TARIHSEL VE POLITTIK TEMELDE KAVRAMAK” Türk tabipleri birliği mesleki sağlık ve güvenlik dergisi,14:3, 3-24.

Avcı, U. (2005) “ İşletmelerde Örgütsel Öğrenme. Örgütsel Performans İlişkisi: Konaklama İşletmelerinde Ö̈rgütsel Öğrenme-Örgütsel Performans İlişkisine Yönelik İnceleme" Süleyman Demirel Üniversitesi Sosyal Bilimler Enstitüsü, Yayınlanmamış Doktora Tezi, Isparta.

Bell,M.P. Özbilgin, M.F. Beauregard, A.T. Ve Sürgevıl, O. (2011) "Voice, Silence, And Diversity İn 21st Century Organizations: Strategies For İnclusion Of Gay, Lesbian, Bisexual, And Transgender Employees" Human Resource Management, 50(1),131-146.

Brimhall, K. Lizano, E. Ve Mor Barak, M. (2014) “The Mediating Role Of İnclusion: A Longitudinal Study Of The Effects Of Leader-Member Exchange And Diversity Climate On Job Satisfaction And İntention To Leave Among Child Welfare Workers" Children And Youth Services Review, 40(9), 79-88.

Colgan, F. Ve Rumen, N. (2015) "Sexual Orientation At Work: Contemporary Issues And Perspectives" Newyork, Routledge Publications.

Cox, T.H. Ve Blake S. (1991) "Managing Cultural Diversity: Implications For Organizational Competitiveness" Academy Of Management Journal, 5(3),45-56.

Day, N.E. Ve Schoenrade, P. (2000) "The Relationship Among Reported Disclosure Of Sexual Orientation, Antidiscrimination Policies, Top Management Support And Work Attitudes Of Gay And Lesbian Employees" Personnel Review, 29(2),346-363.

Day, N.E. Ve Schoenrade, P. (2006) "Staying İn The Closet Versus Coming Out: Relationships Between Communication About Sexual Orientation And Work Attitudes" The Personel Psychology, 119(5), 1744-1763.

Durmuş, B., Yurtkoru, S., Ve Çinko, M. (2012) Sosyal Bilimlerde Spss'le Veri Analizi, (5.Baskı), İstanbul, Beta Yayınevi.

Eagly, A.J. Ve Karau, S.J. (2002) "Role Congruity Theory Of Prejudice Toward Female Leaders" Psychological Review Copyright ,109(8), 573-598.

Elçi, D. Ö. (2018) "Trans-Women Stamped Wıth Discrımınatıon, Hate Speech/Crımes And Transfobı" The Journal Of International Social Research, 11(4), 534-542.

Greenhaus, J. Parasuraman, S. Ve Wormley, W. (1990) “Effect Of Race On Organizational Experiences, Job Performance Evaluations And Career Outcomes" Academy Of Management Journal, 33(4), 64-86.

Hennekam, S. A. M. Ve Ladge, J.J. (2017) "When Lesbians Become Mothers: Identity Validation And The Role Of Diversity Climate" Journal Of Vocatıonal Behavior,103(24), 417-440.

Mckay,P. Avery D. Ve Morris, M. (2008) "Mean Racial-Ethnic Differences In Employeesales Performance: The Moderatıng Role Of Diversity Climate" Personnel Psychology , 61(2), 349-374.

Mckay,P. Avery,D. Tonidandel, S. Morris, M. Hernandez, M. Ve Hebl M.R. (2007) "Racial Differences İn Employee Retention:Are Diversity Climate Perceptions The Key?” Personnel Psychology, 60(5), 35-62.

Öztürk, M.B. (2011) "Sexual Orientation Discrimination: Exploring The Experiences Of Lesbian, Gay And Bisexual Employees İn Turkey" Human Relations, 64(8), 1099-1118.

Özküralpli İ. (2016) “Queer Teori”, İçinde: F. Saygılıgil (Haz.) “Toplumsal Cinsiyet Tartışmaları” Dipnot Yayınları, Ankara.

Pamuk, A. (2017), Kimlik Ve Tarih (2.Baskı), İstanbul: Yeni İnsan Yayınevi.

Ragins, B. R., Singh, R., Ve Cornwell, J. M. (2007) "Making The İnvisible Visible: Fear And Disclosure Of Sexual Orientation At Work" Journal Of Applied Psychology, 92(5), 1103-1118.

Syed, J. Ve Ozbilgin M. (2015) "Managing Diversity And Inclusion: An International Perspective" Londra, Sage Publications.

Yazıcıoğlu, Y. Ve Erdoğan, S. (2004) SPSS Uygulamalı Bilimsel Araştırma Yöntemleri. Ankara: Detay Yayıncılık.

Yardımc1 S., Güçlü Ö (2013) Queer Tahayyül, Sel Yayıncıllk, İstanbul.

Wang, C. L., Ve Ahmed P. K. (2004) “The Development And Validation Of The Organisational İnnovativeness Construct Using Confimatory Factor Analysis" European Journal Of Innovation Management, 10(4): 303-313.

Weeks J. (2016) "Bir Kavramın Anatomisi: Cinsellik”, Çev: İlknur Güzel, Everest Yayınları, İstanbul. 